\title{
Prevalence and association of human papillomavirus 16, Epstein-Barr virus, herpes simplex virus-1 and cytomegalovirus infection with human esophageal carcinoma: A case-control study
}

\author{
DONG-HONG ZHANG ${ }^{1 *}$, QING-YING ZHANG ${ }^{2 *}, \mathrm{CHAO}-Q U N ~ H O N G^{4}$, \\ JIONG-YU CHEN ${ }^{4}$, ZHONG-YING SHEN ${ }^{3}$ and YI ZHU ${ }^{1}$ \\ ${ }^{1}$ Cardiovascular Research Center, ${ }^{2}$ Department of Preventive Medicine, ${ }^{3}$ Institute of Oncology Pathology, \\ Shantou University Medical College, ${ }^{4}$ Department of Medical Oncology, Affiliated Cancer \\ Hospital of Shantou University Medical College, Shantou 515041, P.R. China
}

Received January 4, 2011; Accepted February 28, 2011

DOI: 10.3892/or.2011.1234

\begin{abstract}
Recent research shows esophageal carcinoma (EC) as the ninth most common malignancy in the world. The association of viral infection and $\mathrm{EC}$ has been reported in the last 30 years. However, geographic variation in infection rates and the key mechanisms of the viral action have yet to be resolved. This study aimed to determine the prevalence and association of human papillomavirus 16 (HPV-16), herpes simplex virus 1 (HSV-1), Epstein-Barr virus (EBV) and cytomegalovirus (CMV) infection in the etiology of EC in the area of Shantou, Guangdong, China. Nested PCR was used to detect viral DNA in the mucosa of 70 cases of EC and in paracancerous tissues, as well as 100 cases of normal esophagus mucosa. Data were analyzed by $\chi^{2}$ test, Fisher's exact test and bivariate correlation analysis. The infection rates of HPV-16, HSV-1 and EBV were 40.0, 30.0 and $30.0 \%$, respectively, in EC mucosa, and were significantly higher than those in normal mucosa. However, no CMV DNA was detected in either EC or normal mucosa. HPV-16 or EBV infection was mainly detected in EC patients 48-58 years old, and the infection rate was positively associated with pathological grade of EC $(\mathrm{P}<0.05)$. Tobacco smoking and alcohol consuption were high risk factors for HPV-16 infection for male patients [odds ratio
\end{abstract}

Correspondence to: Dr Yi Zhu, Cardiovascular Research Center, Shantou University Medical College, 22 Xinling Road, Shantou 515041, P.R. China

E-mail: zhuyi@hsc.pku.edu.cn

*Contributed equally

Abbreviations: EC, esophageal carcinoma; HPV-16, human papillomavirus-16; HSV-1, herpes simplex virus-1; EBV, EpsteinBarr virus; $\mathrm{CMV}$, cytomegalovirus; $\mathrm{PCR}$, polymerase chain reaction; IHC, immunohistochemistry; OR, odds ratio; CI, confidence interval

Key words: human papillomavirus 16, Epstein-Barr virus, herpes simplex virus-1, cytomegalovirus, esophageal carcinoma
(OR), 5.9; 95\% confidence interval (CI), 1.4-24.6; OR=3.8; $95 \%$ CI, 1.1-13.8]. Rates of infection with a mixture of these 3 viruses were all more than $10.0 \%$ in cancerous mucosa and closely related to the pathological grade of EC $(\mathrm{P}=0.001)$. Infection with HPV-16, HSV-1 or EBV may be an important etiological factor in EC.

\section{Introduction}

Esophageal carcinoma (EC) occurs worldwide and has a variable geographic distribution (1); the incidence is high in certain areas of China (2-4), especially the area of Shantou, Chaoshan region, in Guangdong, China. The age-standardized incidence rates for EC were 72 to $150 / 10^{5}$ for males and 26 to $64 / 10^{5}$ for females in Nan'ao (a county of the Chaoshan district) between 1995 and 2004 (5). Besides the common factors, such as tobacco smoking, alcohol drinking and dietary deficiency, some other factors, including drinking hot tea and consumption of fermented fish sauce, are involved in the development of EC in this district $(6,7)$. However, the etiology of EC is still under debate.

Increasing evidence has suggested that infection with human papillomavirus (HPV) or human herpesviruses causes several cancer types. Substantial evidence suggests that infection with HPV-16, -18, -45 is a risk factor for cervix, anal, head and neck cancers $(8,9)$. Epstein-Barr virus (EBV) is the causal agent of infectious mononucleosis and is closely associated with Burkitt's lymphoma, nasopharyngeal carcinoma and opportunistic B-cell lymphoma in immunocompromised hosts $(10,11)$. Herpes simplex virus 1 (HSV-1) infection occurs mainly in the mouth and is associated with oral cancer (12). Cytomegalovirus (CMV), a common human pathogen, may be associated with cervical and non-melanoma skin cancer $(13,14)$. Nevertheless, previous studies showed that the prevalence of infection with HSV, EBV and CMV (3 ubiquitous herpes viruses) and HPV varied widely in EC specimens, depending on, for example, the population, type of specimen, racial difference, the sensitivity of the detection technique or the study methods $(11,15)$. The underlying mechanism of viral infection remains unknown. Thus, the association of 
Table I. PCR primer sequences of 4 viruses and $\beta$-actin.

\begin{tabular}{|c|c|c|c|c|}
\hline Gene & Primer & Primer sequence $\left(5^{\prime} \rightarrow 3^{\prime}\right)$ & Products (bp) & $\mathrm{AT}^{\mathrm{a}}\left({ }^{\circ} \mathrm{C}\right)$ \\
\hline \multirow[t]{4}{*}{ HPV-16 } & $\mathrm{F}^{\mathrm{b}}$ & ACTCGAG/TTTATGCACCAAAAGAGAAC & 541 & 58.0 \\
\hline & $\mathrm{R}^{\mathrm{c}}$ & GATCAGTTGTCTCTGGTTGC & & \\
\hline & $\mathrm{F}$ & TTCAGGACCCACAGGAGC & 452 & 61.0 \\
\hline & $\mathrm{R}$ & TCACCCC/TGATTACAGCTGGGTTTC & & \\
\hline \multirow[t]{4}{*}{ EBV } & $\mathrm{F}$ & AGGGATGCCTGGACACAAGAG & 597 & 53.2 \\
\hline & $\mathrm{R}$ & TGGTGCTGCTGGTGGTGGCAA & & \\
\hline & $\mathrm{F}$ & TCTTGATAGGATCCGCTAGGATA & 497 & 60.0 \\
\hline & $\mathrm{R}$ & ACGAGGTTCTGGACTATCAGGATC & & \\
\hline \multirow[t]{4}{*}{ HSV-1 } & $\mathrm{F}$ & TACATCGGCGTCATCTACGGGG & 330 & 56.0 \\
\hline & $\mathrm{R}$ & GGGCCAGGCGCTTGTTGGTGTA & & \\
\hline & $\mathrm{F}$ & CAGTTCGGCGGTGAGGACAAA & 136 & 61.3 \\
\hline & $\mathrm{R}$ & GCGT T TA TCAA CCGCA CCTCC & & \\
\hline \multirow[t]{4}{*}{ CMV } & $\mathrm{F}$ & TGAGGATAAGCGGGAGATGT & 242 & 56.0 \\
\hline & $\mathrm{R}$ & ACTGAGGCAAGTTCTGCAGT & & \\
\hline & $\mathrm{F}$ & AGCTGCATGATGTGAGCAAG & 146 & 59.0 \\
\hline & $\mathrm{R}$ & GAAGGCTGAGTTCTTGGTAA & & \\
\hline \multirow[t]{2}{*}{$\beta$-actin } & $\mathrm{R}$ & CTGCCGTTTTGCGTAGGAC & 426 & 55.1 \\
\hline & $\mathrm{F}$ & AGGCGTACAGGGATAGCAC & & \\
\hline
\end{tabular}

${ }^{\mathrm{a}}$ Annealing temperature. ${ }^{\mathrm{b}}$ Forward. ${ }^{\mathrm{c}}$ Reverse.

HPV-16, HSV-1, EBV or CMV infection and the development of human EC is still unclear.

To determine whether these 4 viruses could have a role in the etiology of EC, we studied the association of infection with high-risk HPV-16 and the 3 common herpes viruses (HSV-1, EBV and CMV) and EC by nested PCR in normal mucosa, cancerous mucosa, and paracancerous tissues collected from the Shantou region.

\section{Materials and methods}

Participants. The study was carried out in compliance with the Helsinki Declaration and approved by the Ethics Committee of Shantou University Medical College. All patients gave written informed consent (Cardiovascular Research Center, Shantou University Medical College, China and Department of Medical Oncology, Affiliated Cancer Hospital of Shantou University Medical College, China). We selected 70 cases of EC from the Affiliated Tumor Hospital of Shantou University Medical College from 2000 to 2006. Patients were living in Shantou, a coastal region of eastern Guangdong province, China. All resected specimens were sent for routine histological evaluation, and a pathological diagnosis was made. Every fresh specimen was divided into 2 parts: cancerous tissues and paracancerous normal tissues (dissected from an area $\geq 7 \mathrm{~cm}$ away from the tumor lesions). A new microtome blade was used for each cut to avoid contamination of the samples. Among the 70 patients, mean age was $57.3 \pm 1.08$ years, range 40-78 years, and 49 were male.

The control samples were fresh esophageal tissues dissected from 100 cancer-free subjects who died due to trauma, in the hospital or daily life (mainly traffic accidents and regular daily labour), or to cardiocerebrovascular disease, but their esophagus was normal on histopathology. These subjects, who lived in the Shantou region, had mean age 32.36 \pm 0.98 years, range 17-59 years, and 77 were male.

Informed consent was obtained from each subject, and personal data regarding demographic characteristics such as gender, age and related risk factors, including alcohol consumption and smoking habits, were collected via questionnaire from each participant after an interview with a trained interviewer. Alcohol drinkers were as those who had consumed wine, beer or distilled spirits more than once per week for at least 1 year. Those who had smoked $>10$ cigarettes per week for at least 1 year were defined as cigarette smokers.

Tissue processing. Specimens were fixed in $40 \mathrm{ml} / 1$ neutral buffered formalin with 1/1000 diethylpyrocarbonate (DEPC, Sigma Chemical Co., St. Louis, MO, USA) and embedded in paraffin. The $10-\mu \mathrm{m}$-thick tissue samples used for DNA extraction were resected with a fresh blade to reduce the risk of contamination.

DNA extraction. Five $10-\mu \mathrm{m}$-thick pieces of tissue were placed in a sterile 1.5-ml Eppendorf tube and filled with $400 \mu \mathrm{l}$ lysis buffer $(10 \mathrm{mM}$ Tris- $\mathrm{HCl}, \mathrm{pH} 8.3 ; 50 \mathrm{mM} \mathrm{KCl}$; $2.5 \mathrm{mM} \mathrm{MgCl}_{2} ; 0.45 \%$ Tween-20). The tube was placed in a heat block (Thermolyne dry-bath) for incubation at $70^{\circ} \mathrm{C}$ for $1 \mathrm{~h}$ and then was centrifuged at $12,000 \mathrm{rpm}$ for $5 \mathrm{~min}$ at room temperature $\left(25^{\circ} \mathrm{C}\right)$. Paraffin solidified on the top of the buffer and was removed from the tube by use of a sterile pipette tip. The sample tubes were incubated at $60^{\circ} \mathrm{C}$ for $2 \mathrm{~h}$ after the addition of $20 \mu \mathrm{l}$ proteinase K $(20 \mathrm{mg} / \mathrm{ml})$ (Sigma Chemical Co.). To inactivate proteinase $\mathrm{K}$ after digestion, the samples 


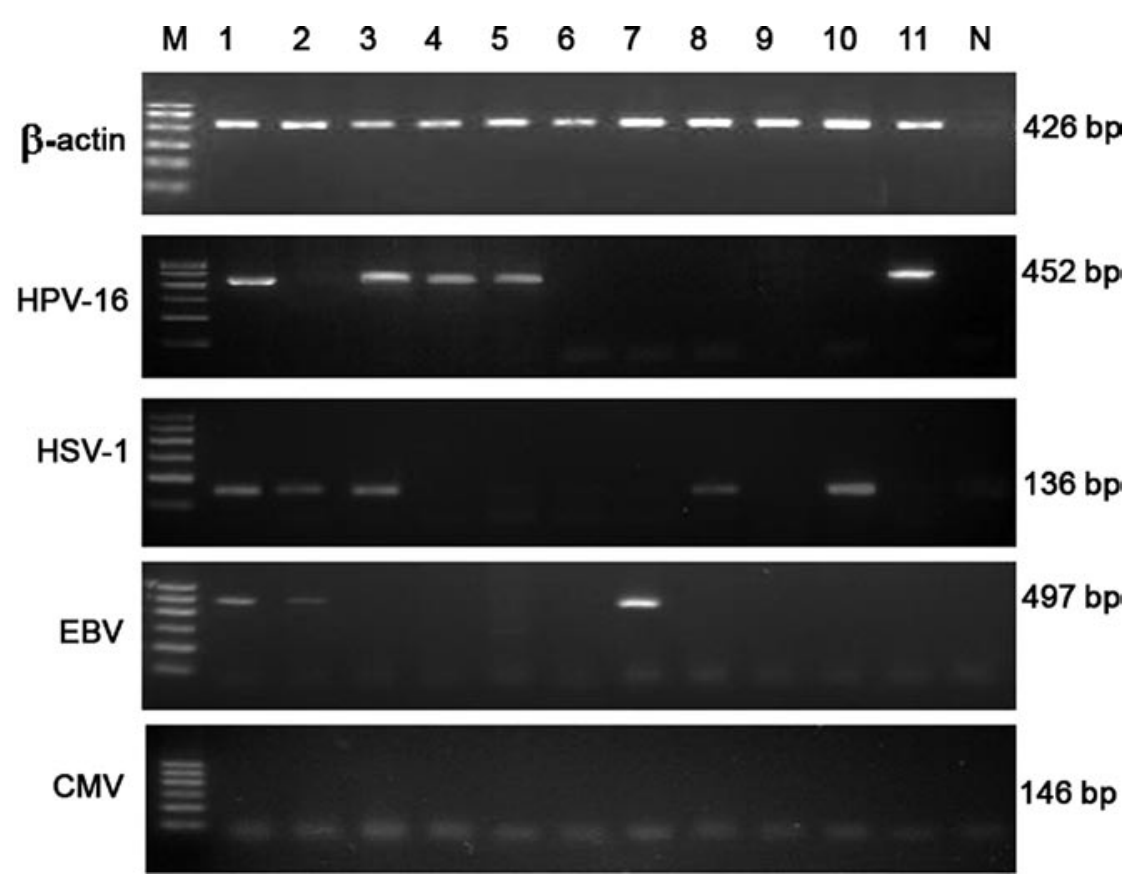

Figure 1. Electrophoretic profile of nested PCR products amplified from the 4 viruses in esophageal lesions. The gel image shows 11 representatives of the 240 nested PCR reactions analyzed by Eppendorf Mastercycler Gradient. $\beta$-actin DNA from each sample was amplified from normal PCR for DNA quality control. M, DNA marker; and N, negative control.

were boiled for $10 \mathrm{~min}$ and centrifuged at $12,000 \mathrm{rpm}$ for 5 min. The supernatants containing DNA were transferred to a new, sterile micro-concentrator (Millipore Corp., Billerica, MA), and DNA purification was performed as per the manufacturer's instructions. After air drying at room temperature, DNA was dissolved in TE-buffer $(10 \mathrm{mM}$ Tris- $\mathrm{HCl}, 1 \mathrm{mM}$ EDTA, pH 7.8) and stored at $-80^{\circ} \mathrm{C}$.

Validation of PCR reactions. Human $\beta$-actin DNA was screened by normal PCR amplification of a 426-bp product, which provided an indication of good DNA quality for each sample.

Detection of HPV-16, HSV-1, EBV, CMV by nested PCR. Each $\mathrm{PCR}$ reaction was carried out in a total volume of $50 \mu$ l containing $2 \mu l$ purified DNA and $5 \mu l 10 X$ PCR buffer $[10 \mathrm{mmol} / 1$ Tris- $\mathrm{HCl}$ (pH 8.3), $50 \mathrm{mmol} / 1 \mathrm{KCl}$ and $2.5 \mathrm{mmol} / 1 \mathrm{MgCl}_{2}, 20 \mathrm{mmol} / \mathrm{l}$ deoxynucleotide triphosphate], $1 \mathrm{mmol} / \mathrm{l}$ primers and 1.25 units of TaqDNA polymerase (Promega Corp., Madison, WI). The high-risk HPV-16 gene was first amplified with use of external primers (Table I), and the PCR product was $541 \mathrm{bp}$. PCR amplification involved activation for $5 \mathrm{~min}$ at $94^{\circ} \mathrm{C}$, then 30 cycles of $40 \mathrm{sec}$ at 94,58 and $72^{\circ} \mathrm{C}$, with a final extension of $10 \mathrm{~min}$ at $72^{\circ} \mathrm{C}$. Then $1 \mu \mathrm{l}$ of the first-round PCR product was used as the template for the following nested PCR ( 35 cycles), with conditions identical to the first-round PCR, with the exception of the use of $1 \mathrm{mmol} / \mathrm{l}$ of internal primers and annealing at $61^{\circ} \mathrm{C}$ for $40 \mathrm{sec}$. The final products were resolved in $1.5 \%(\mathrm{~g} / \mathrm{ml})$ agarose gel containing ethidium bromide $(0.2 \mathrm{mg} / \mathrm{l})$, for gel purification and sequencing of the positive band. The individual sequence was then used in a BLAST search of HPV-16 sequences in GenBank (http://www.ncbi.nlm.nih.gov). HSV-1, EBV and CMV amplification by nested PCR was as described previously (16-18), and the primers for each are in Table I.
The study was repeated and confirmed by the Department of Medical Oncology, Affiliated Cancer Hospital of Shantou University Medical College.

Statistical analysis. The presence of viral DNA in EC and normal esophageal tissue was analyzed by $\chi^{2}$. The association with co-infection was measured by Bivariate correlation analysis. $\chi^{2}$ test or Fisher's exact test was used to analyze the risk factors of viral infection for EC patients. A two-sided $\mathrm{P}<0.05$ was considered statistically significant. All analyses involved use of SPSS v13.0 (SPSS Inc., Chicago, IL).

\section{Results}

Overall prevalence of 4 viruses. All samples were randomly coded and processed in a blinded manner for screening the DNA for the 4 viruses by nested PCR (Fig. 1). HPV-16 was the most frequent infection in EC tissues (40.0\%) and paracancerous mucosae (35.7\%), then HSV-1 (30.0 and 22.9\%, respectively) and EBV (30.0 and 7.4\%, respectively) (Table II). Infection rates for all 3 viruses were significantly higher in EC tissue than in normal mucosa. The odds ratio (OR) was 7.7 [95\% confidence interval (CI), 3.2-18.2] for HPV-16 infection, 2.4 (95\% CI, 1.1-5.1) for HSV-1 infection and 10.3 (95\% CI, 3.3-31.6) for EBV infection. However, no tissue was positive for CMV. Infection with multiple viruses was common in cancerous tissues: 13 cases showed infection with HPV-16 and HSV-1, 10 with HPV-16 and EBV, 11 with HSV and EBV, and 7 with HPV-16, HSV-1 and EBV. All these mixed infection rates were markedly lower in paracancerous and normal mucosae than in EC tissue. Interestingly, $46.4 \%$ (13/28) of HPV-positive specimens showed HSV-1 infection $(\mathrm{P}=0.014)$ and $35.7 \%(16 / 28)$ EBV infection $(\mathrm{P}=0.394)$ and 
Table II. Infection with 4 viruses in esophageal specimens.

\begin{tabular}{lccc}
\hline Virus & $\begin{array}{c}\text { Normal } \\
\text { mucosa } \\
\text { no. }(\%)\end{array}$ & $\begin{array}{c}\text { Paracancerous } \\
\text { mucosa } \\
\text { no. }(\%)\end{array}$ & $\begin{array}{c}\text { Cancerous } \\
\text { tissues } \\
\text { no. }(\%)\end{array}$ \\
\hline Total no. & 100 & 70 & 70 \\
HPV-16 & $8(8.0)$ & $25(35.7)^{\mathrm{a}}$ & $28(40.0)^{\mathrm{a}}$ \\
HSV-1 & $15(15.0)$ & $16(22.9)$ & $21(30.0)^{\mathrm{b}}$ \\
EBV & $4(4.0)$ & $5(7.1)$ & $21(30.0)^{\mathrm{a}}$ \\
CMV & 0 & 0 & 0 \\
HPV16+HSV & $5(5.0)$ & $13(18.6)^{\mathrm{a}}$ & $13(18.6)^{\mathrm{a}}$ \\
HPV16+EBV & $3(3.0)$ & $4(5.7)$ & $10(14.3)^{\mathrm{a}}$ \\
HSV+EBV & $1(1.0)$ & $3(4.3)$ & $11(15.7)^{\mathrm{a}}$ \\
HPV16+HSV+EBV & 0 & $3(4.3)$ & $7(10.0)^{\mathrm{a}}$ \\
\hline
\end{tabular}

${ }^{\mathrm{a}} \mathrm{P}<0.01,{ }^{\mathrm{b}} \mathrm{P}<0.05$ compared with normal esophagus mucosa, and calculated with the Pearson $\chi^{2}$ test or Fisher's exact test.

Table III. Association of co-infection with HPV-16, HSV-1 and EBV in EC.

\begin{tabular}{lccc}
\hline P-value $^{\mathrm{a}}$ & HPV-16 & HSV-1 & EBV \\
\hline HPV-16 & 1.000 & 0.014 & 0.394 \\
HSV-1 & - & 1.000 & 0.007 \\
EBV & - & - & 1.000 \\
\hline
\end{tabular}

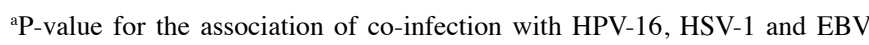
calculated with the Bivariate correlation analysis.

$52.4 \%(11 / 21)$ of HSV-1-positive specimens showed EBV infection $(\mathrm{P}=0.007)$. Therefore, co-infection with HPV-16 and HSV-1, and EBV and HSV-1 was present (Table III).

Relationship between viral infection and clinical features. On multivariate analysis, age, especially the age range 48-58 years, in patients with EC was associated with HPV-16 infection (Table IV). HPV infection increased with decreasing age of EC patients $(\mathrm{P}=0.036)$ and pathological grade of $\mathrm{EC}(\mathrm{P}=0.001)$. Moreover, HPV-16 infection was associated with tobacco smoking and alcohol drinking for male EC subjects: the OR was 5.9 (95\% CI, 1.4-24.6, $\mathrm{P}=0.010)$ for smoking as compared with not smoking and $3.8(95 \% \mathrm{CI}, 1.1-13.8, \mathrm{P}=0.035)$ for alcohol drinking as compared with not drinking. HSV-1 infection was also associated with increasing pathological grade of EC $(\mathrm{P}<0.05)$. Infection with HPV-16 and HSV-1, HSV-1 and EBV, or HPV-16, HSV-1 and EBV was associated with increasing pathological grade of EC $(\mathrm{P}<0.05)$ (Table V).

\section{Discussion}

The development of EC is a multifactor and multistage process with contributing factors varying by geographic region. The Chaoshan district in China is the only coastal high-incidence area of EC, and subjects with EC show specific characteristics. Previous evidence has suggested a role of microorganisms such as HPV and HSV-1 in EC. HPV infection has been extensively studied in vivo and in vitro (19-22). The involvement of HPV infection in both benign $(60.0 \%)$ and malignant human esophageal lesions $(65.5 \%)$ has been demonstrated by morphological or molecular biological studies, and DNA evidence of high-risk HPV-16 and -18 was more common in cancerous tissues than in paracancerous and normal mucosa (23).

To determine the role of HPV-16 and the selective herpesviridae family viruses (HSV-1, EBV and CMV) in the etiology of EC, we used nested PCR assay, one of the most sensitive and specific detection techniques, to systematically detect the DNA of the 4 viruses in esophageal lesions. The samples included the mucosa of 70 cases of EC and paracancerous tissues, as well as 100 normal esophageal mucosa, collected from the Shantou region of China. HPV-16 was the most common infection in EC or paracancerous mucosae, then HSV-1 and EBV infection. The rates of infection of the 3 viruses in EC tissue were significantly higher than that in normal mucosa, with no difference among the 3 tissue types in HSV-1 infection. HSV-1 infection is associated with esophagitis, which suggests that HSV-1 infection is common in the esophagus. EBV infection rate in EC tissues was higher than that in paracancerous mucosae or normal esophageal tissue. However, we found no esophageal tissue positive for CMV. Our results for HPV infection agree with those from Gansu province in China: $65 \% \mathrm{HPV}$ infection with EC detected by INNO-LiPA HPV genotyping (24). Our results for HSV infection agree with those from Shantou region in China: $31.7 \%$ HSV infection in EC detected by immunohistochemistry (IHC) (15). Our results for EBV infection agree with those from Taiwan (35.5\% EBV infection with EC detected by normal PCR) (25) and Germany (35\% EBV infection with EC detected by nested PCR) (26). Interestingly, EBV DNA detection in our study was higher than EBV EBER and LMP-1 protein detection (6.7 and 6.1\%) by in situ hybridization (for mRNA) and immunohistochemistry (13), which may due to the high-sensitive and specific detection techniques we used. Finally, our results for CMV infection agree with those from He'nan province in China: 0\% CMV infection with EC detected by immunohistochemistry (27). However, our results for the detection rates of HPV-16, HSV-1 and EBV in EC were notably higher than those from other high-incidence areas (28-32), which may due to our use of high-sensitive and specific detection technology and study of the high-risk area of Shantou.

Based on a previous study (27), we thought that more sensitive method was necessary for the relatively low viral load infection in most positive EC tumors. Firstly, attempt to examine the efficiency of nested PCR compared with regular PCR take HPV L1 gene detection for example, we constructed plasmid (pGEX-4T-2) DNA containing HPV L1 gene. The plasmid stock solutions were diluted in sterile water to obtain a quantification gradient of 1, 2, 4, 8, 16, 32, 64, 128 and 256 copies for HPV L1 gene. Gel electrophoresis analysis showed that nested PCR can detectable limited to 1 copy HPV DNA, but 256 copies for regular PCR amplification with use of the consensus primer MY09/11 (data not shown). On the other hand, high sensitivity compared with more risk of contamination in PCR amplification. Thus, strict negative control, careful 
Table IV. Relation of infection with a single virus and clinical characteristics of the patients with esophageal cancer, as well as the age and gender of control subjects.

\begin{tabular}{|c|c|c|c|c|c|c|c|}
\hline Characteristics & $\begin{array}{c}\text { Cases } \\
\text { (n) }\end{array}$ & $\begin{array}{c}\text { HPV-16 } \\
\text { positive (n) }\end{array}$ & P-value ${ }^{a}$ & $\begin{array}{c}\text { HSV-1 } \\
\text { positive (n) }\end{array}$ & P-value ${ }^{a}$ & $\begin{array}{c}\text { EBV } \\
\text { positive (n) }\end{array}$ & P-value ${ }^{a}$ \\
\hline EC patients & 70 & 28 & & 21 & & 21 & \\
\hline \multicolumn{8}{|l|}{ Gender } \\
\hline Male & 49 & 22 & 0.201 & 14 & 0.690 & 16 & 0.459 \\
\hline Female & 21 & 6 & & 7 & & 5 & \\
\hline \multicolumn{8}{|l|}{ Age (years) } \\
\hline $38-47$ & 8 & 3 & 0.036 & 2 & 0.623 & 0 & 0.093 \\
\hline $48-57$ & 31 & 18 & & 11 & & 11 & \\
\hline $58-67$ & 20 & 4 & & 4 & & 7 & \\
\hline $68-78$ & 11 & 3 & & 4 & & 3 & \\
\hline \multicolumn{8}{|c|}{ Lymph node metastasis } \\
\hline Yes & 29 & 11 & 0.766 & 10 & 0.491 & 10 & 0.491 \\
\hline No & 41 & 17 & & 11 & & 11 & \\
\hline \multicolumn{8}{|l|}{ Cancer grade } \\
\hline I & 29 & 10 & 0.001 & 6 & 0.022 & 6 & 0.209 \\
\hline II & 26 & 6 & & 6 & & 8 & \\
\hline III & 15 & 12 & & 9 & & 7 & \\
\hline \multicolumn{8}{|c|}{ Tobacco smoking (male) } \\
\hline Yes & 33 & 19 & 0.010 & 10 & 0.962 & 12 & 0.426 \\
\hline No & 16 & 3 & & 4 & & 4 & \\
\hline \multicolumn{8}{|c|}{ Alcohol drinking (male) } \\
\hline Yes & 15 & 10 & 0.042 & 6 & 0.405 & 5 & 1.000 \\
\hline No & 34 & 12 & & 8 & & 11 & \\
\hline Control subjects & 100 & 22 & & 15 & & 6 & \\
\hline \multicolumn{8}{|l|}{ Gender } \\
\hline Male & 77 & 15 & 0.266 & 13 & 0.527 & 4 & 0.904 \\
\hline Female & 23 & 7 & & 2 & & 2 & \\
\hline \multicolumn{8}{|l|}{ Age (years) } \\
\hline $17-27$ & 37 & 7 & 0.941 & 6 & 0.842 & 1 & 0.672 \\
\hline $28-37$ & 36 & 9 & & 7 & & 3 & \\
\hline $38-47$ & 18 & 4 & & 2 & & 1 & \\
\hline $48-60$ & 9 & 2 & & 1 & & 1 & \\
\hline
\end{tabular}

${ }^{\text {a} P-v a l u e s ~ f o r ~ t h e ~ d i f f e r e n c e s ~ b e t w e e n ~ v i r a l ~ p o s i t i v e ~ a n d ~ n e g a t i v e ~ g r o u p s ~ c a l c u l a t e d ~ w i t h ~ t h e ~ P e a r s o n ~} \chi^{2}$ test or Fisher's exact test.

operation and subarea regulation for reagents were necessary to avoid contamination. We performed inter-laboratory and parallel study to attempt to overcome the problems mentioned by independently analyzing of the nested PCR amplification, and each independent laboratory performed the tests twice. At present we detected only viral prevalence, not viral transcription and expression, or the mechanism of carcinogenesis in EC tissue. Thus, further study is needed to confirm DNA prevalence result to clearly understand the relation of viral infection and EC.

Immediate-early gene products of HPV can transactivate other viral and cellular genes, and concurrent genital infection with CMV and HSV-1 might increase the risk of cervical cancer (33). Therefore, mixed viral infection is more important in carcinogenesis than is single virus infection. Similarly, we found that infection with a mixture of viruses was common in EC tissue. For example, the rates of dual infection with HPV-16 and HSV-1, HPV-16 and EBV, and HSV-1 and EBV and triple infection with HPV-16, HSV-1 and EBV were all more than $14.3 \%$; however, in normal esophagus mucosa, the dual infection rates were lower than $5 \%$, and no rates of triple infection were found. Further statistical analysis showed positivity for HPV-16, HSV-1 or EBV single infection was mainly in EC patients aged 48-58 years and was positively associated with pathological grade of EC. Viral infection may have a dual function of initiating and maintaining carcinogenesis. As well, in male EC patients, HPV-16 infection was prevalent in heavy smokers or alcohol drinkers. This finding might be explained by the high risk of viral infection induced by low immunity, production of carcinogens and direct interaction 
Table V. Relationship between infection with mixed viruses and clinical characteristics of patients with esophageal cancer, as well as age and gender of control subjects.

\begin{tabular}{|c|c|c|c|c|c|c|c|c|c|}
\hline Characteristics & $\begin{array}{c}\text { Cases } \\
(\mathrm{n})\end{array}$ & $\begin{array}{l}\text { HPV-16+HSV-1 } \\
\text { positive (n) }\end{array}$ & P-value ${ }^{a}$ & $\begin{array}{l}\text { HPV-16+EBV } \\
\text { positive (n) }\end{array}$ & P-value ${ }^{a}$ & $\begin{array}{c}\text { HSV-1+EBV } \\
\text { positive (n) }\end{array}$ & P-value ${ }^{a}$ & $\begin{array}{l}\text { HPV-16+HSV-1+EBV } \\
\text { positive (n) }\end{array}$ & P-value \\
\hline EC patients & 70 & 13 & & 10 & & 11 & & 7 & \\
\hline \multicolumn{10}{|l|}{ Gender } \\
\hline Male & 49 & 11 & 0.348 & 9 & 0.264 & 7 & 0.886 & 6 & 0.602 \\
\hline Female & 21 & 2 & & 1 & & 4 & & 1 & \\
\hline \multicolumn{10}{|l|}{ Age (years) } \\
\hline $38-47$ & 8 & 1 & 0.128 & 0 & 0.115 & 0 & 0.229 & 0 & 0.053 \\
\hline $48-57$ & 31 & 7 & & 7 & & 7 & & 5 & \\
\hline $58-67$ & 20 & 1 & & 1 & & 2 & & 0 & \\
\hline $68-78$ & 11 & 4 & & 2 & & 2 & & 2 & \\
\hline \multicolumn{10}{|l|}{$\begin{array}{l}\text { Lymph node } \\
\text { metastasis }\end{array}$} \\
\hline Yes & 29 & 5 & 0.801 & 4 & 1.000 & 5 & 1.000 & 2 & 0.746 \\
\hline No & 41 & 8 & & 6 & & 6 & & 5 & \\
\hline \multicolumn{10}{|l|}{ Cancer grade } \\
\hline I & 29 & 3 & 0.001 & 3 & 0.009 & 3 & 0.142 & 2 & 0.003 \\
\hline II & 26 & 2 & & 1 & & 3 & & 0 & \\
\hline III & 15 & 8 & & 6 & & 5 & & 5 & \\
\hline \multicolumn{10}{|l|}{$\begin{array}{l}\text { Tobacco } \\
\text { smoking (male) }\end{array}$} \\
\hline Yes & 33 & 8 & 0.947 & 7 & 0.730 & 5 & 1.000 & 4 & 1.000 \\
\hline No & 16 & 3 & & 2 & & 2 & & 2 & \\
\hline \multicolumn{10}{|l|}{$\begin{array}{l}\text { Alcohol } \\
\text { drinking (male) }\end{array}$} \\
\hline Yes & 15 & 5 & 0.400 & 3 & 1.000 & 3 & 0.752 & 1 & 1.000 \\
\hline No & 34 & 6 & & 6 & & 4 & & 3 & \\
\hline Control subjects & 100 & 5 & & 3 & & 1 & & 0 & \\
\hline \multicolumn{10}{|l|}{ Gender } \\
\hline Male & 77 & 3 & $-\mathrm{b}$ & 2 & $-^{\mathrm{b}}$ & 1 & $-^{\mathrm{b}}$ & 0 & $-b$ \\
\hline Female & 23 & 2 & & 1 & & 0 & & 0 & \\
\hline \multicolumn{10}{|l|}{ Age (years) } \\
\hline $17-27$ & 37 & 0 & $-\mathrm{b}$ & 0 & $-\mathrm{b}$ & 0 & $-\mathrm{b}$ & 0 & $-{ }^{b}$ \\
\hline $28-37$ & 36 & 2 & & 1 & & 1 & & 0 & \\
\hline $38-47$ & 18 & 2 & & 1 & & 0 & & 0 & \\
\hline $48-60$ & 9 & 1 & & 1 & & 0 & & 0 & \\
\hline
\end{tabular}

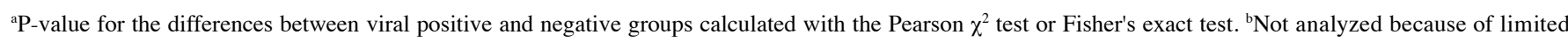
number of cases.

with the host cells. Especially, mixed infection with HPV-16, HSV-1 and EBV might be associated with a high grade of EC but not with the other characteristics of EC patients, such as gender, alcohol drinking, tobacco smoking or lymph node metastasis. Consistent with previous research into mixed viral infection in some malignant tumors, such as cervical $(33,34)$, breast (35) oral (12) and urinary bladder cancers (36), our study further verified that mixed infection with HPV-16, HSV-1 and EBV was involved in the development of EC and might be a leading cause in the pathogenesis of EC.
Shantou may be a unique region for the etiology of EC. Our previous data confirmed that EC is associated with HPV infection, which is consistent findings from other highincidence areas of EC in the world $(20,37,38)$. However, data are lacking on the association with EBV infection. Another study with in situ hybridization and immunohistochemistry in the Shantou region showed the involvement of HSV and EBV infection in EC and the association of HSV and EBV infection and EC cell differentiation with lymphocyte infiltration in the tumor stroma (15). According to previous studies, geographic 
variation was found with HPV infection with EC, as well as with EBV and HSV infection with EC $(31,39,40)$.

Although EBV DNA or RNA can be detected in EC tissue (1.8-35.5\%), EBV was found in tumor-infiltrating lymphocytes, but not tumor cells. Thus, the EBV genome and its transcription may be derived from infiltrating lymphocytes. Cells that carry EBV reach anywhere in the body, and the chance for an epithelial cell to be exposed to EBV is similar at different sites of the gastrointestinal tract $(18,29,32)$. We also confirmed this hypothesis in our study; we found more EBV-infected tissues with than without lymph node metastasis, but the differences were not significant. This finding might result from our use of high-sensitive nested PCR assay, which can detect even 1 copy of the target genome, so even minor B-lymphocyte metastasis carrying EBV to the esophagus can be detected.

Primary viral infection often regresses spontaneously. The advocates of the 'hit-and-run' theory of infection believe that HPV or herpesviruses is a transformation-initiating factor, and they explain problems with direct detection of this infection in carcinoma cells as being due to elimination of viral DNA in the course of oncogenesis (41). However, prolonged and persistent infection is more important than spontaneous infection. For example, the high risk of HPV infection is strongly associated with malignant lesions and leads to virus integration with the host cell genome and valid and long-term expression of viral oncogenes (42-44). As a consequence, EBV infection can become immortalized by the expression of a number of genes. The EBV proteins may mimic the actions of growth factors, transcription factors, and anti-apoptotic factors that interfere with control of the cellular pathways, thus favoring the development of malignancy $(45,46)$. Lately, use of the minimal promoter region of MK to drive the HSV-TK gene and in vivo electroporation to transduce interleukin 21 DNA into tumors produced an efficient gene therapy with improved safety (47). Thus, detecting the presence, quantity and location of various viruses in the development of EC is crucial.

Previous data suggest that co-infection with herpesviruses, especially CMV and/or EBV, may be involved in integration of the HPV-16 genome and may contribute to the development of cervical cancer (33). Similarly, co-infection with herpesviruses, especially HSV-1 and/or EBV, may be involved in HPV-16 genome infection and may contribute to the development of EC in the Shantou region.

This current study showed that infection with HPV-16, HSV-1 and EBV but not CMV is associated with EC in a highrisk area, Shantou region, Guangdong, China. EC patients aged 48-58 years showed infection with single or a mixture of viruses. HPV-16 or HSV-1 infection appears to be positively associated with pathological grade of EC. Tobacco smoking and alcohol drinking are high risk factors for HPV-16 infection in male EC patients. Mixed viral infection, especially HPV-16 co-infection with HSV-1 and/or EBV, is associated with a high grade of EC. Our study supports a causal association of viral infection with esophageal malignancies.

\section{Acknowledgements}

This research was supported by a LC0104 grant of Shantou University Medical College and partially supported by grants from the Guangdong Scientific Fund Key Items (No. 37788, No. 5104541, No.7118419).

\section{References}

1. Parkin DM, Bray F, Ferlay J and Pisani P: Global cancer statistics, 2002. CA Cancer J Clin 55: 74-108, 2005.

2. Qiao YL, Hou J, Yang L, He YT, Liu YY, Li LD, Li SS, Lian SY and Dong ZW: The trends and preventive strategies of esophageal cancer in high-risk areas of Taihang Mountains, China. Zhongguo Yi Xue Ke Xue Yuan Xue Bao 23: 10-14, 2001.

3. Cheng KK: The etiology of esophageal cancer in Chinese. Semin Oncol 21: 411-415, 1994.

4. Kamangar F, Qiao YL, Schiller JT, Dawsey SM, Fears T, Sun XD, Abnet CC, Zhao P, Taylor PR and Mark SD: Human papillomavirus serology and the risk of esophageal and gastric cancers: results from a cohort in a high-risk region in China. Int J Cancer 119: 579-584, 2006.

5. Su M, Liu M, Tian DP, Li XY, Zhang GH, Yang HL, Fan X, Huang HH and Gao YX: Temporal trends of esophageal cancer during 1995-2004 in Nanao Island, an extremely high-risk area in China. Eur J Epidemiol 22: 43-48, 2007.

6. Ke L, Yu P and Zhang ZX: Novel epidemiologic evidence for the association between fermented fish sauce and esophageal cancer in South China. Int J Cancer 99: 424-426, 2002.

7. Ke L, Yu P, Zhang ZX, Huang SS, Huang G and Ma XH: Congou tea drinking and oesophageal cancer in South China. $\mathrm{Br}$ J Cancer 86: 346-347, 2002.

8. Burk RD, Chen Z and van Doorslaer K: Human papillomaviruses: genetic basis of carcinogenicity. Public Health Genomics 12: 281-290, 2009.

9. McLaughlin-Drubin ME and Munger K: Oncogenic activities of human papillomaviruses. Virus Res 143: 195-208, 2009.

10. Awerkiew S, zur HA, Baldus SE, Holscher AH, Sidorenko SI, Kutsev SI and Pfister HJ: Presence of Epstein-Barr virus in esophageal cancer is restricted to tumor infiltrating lymphocytes. Med Microbiol Immunol 194: 187-191, 2005.

11. Lyronis ID, Baritaki S, Bizakis I, Tsardi M and Spandidos DA: Evaluation of the prevalence of human papillomavirus and Epstein-Barr virus in esophageal squamous cell carcinomas. Int J Biol Markers 20: 5-10, 2005.

12. Yang YY, Koh LW, Tsai JH, Tsai CH, Wong EF, Lin SJ and Yang CC: Involvement of viral and chemical factors with oral cancer in Taiwan. Jpn J Clin Oncol 34: 176-183, 2004.

13. Tan HH and Goh CL: Viral infections affecting the skin in organ transplant recipients: epidemiology and current management strategies. Am J Clin Dermatol 1 7: 13-29, 2006.

14. Han XY: Epidemiologic analysis of reactivated cytomegalovirus antigenemia in patients with cancer. J Clin Microbiol 45: 1126-1132, 2007.

15. Wu MY, Wu XY and Zhuang CX: Detection of HSV and EBV in esophageal carcinomas from a high-incidence area in Shantou China. Dis Esophagus 18: 46-50, 2005.

16. Bodaghi S, Yamanegi K, Xiao SY, Da CM, Palefsky JM and Zheng ZM: Colorectal papillomavirus infection in patients with colorectal cancer. Clin Cancer Res 11: 2862-2867, 2005.

17. Brytting M, Sundqvist VA, Stalhandske P, Linde A and Wahren B: Cytomegalovirus DNA detection of an immediate early protein gene with nested primer oligonucleotides. J Virol Methods 32: 127-138, 1991.

18. Chen PC, Pan CC, Hsu WH, Ka HJ and Yang AH: Epstein-Barr virus-associated lymphoepithelioma-like carcinoma of the esophagus. Hum Pathol 34: 407-411, 2003.

19. Chen HB, Chen L, Zhang JK, Shen ZY, Su ZJ, Cheng SB and Chew EC: Human papillomavirus 16 E6 is associated with the nuclear matrix of esophageal carcinoma cells. World $\mathrm{J}$ Gastroenterol 7: 788-791, 2001.

20. Shen ZY, Xu LY, Chen XH, Cai WJ, Shen J, Chen JY, Huang TH and Zeng Y: The genetic events of HPV-immortalized esophageal epithelium cells. Int J Mol Med 8: 537-542, 2001.

21. Shen ZY, Xu LY, Li EM, Cai WJ, Shen J, Chen MH, Cen S, Tsao SW and Zeng Y: The multistage process of carcinogenesis in human esophageal epithelial cells induced by human papillomavirus. Oncol Rep 11: 647-654, 2004.

22. Qi ZL, Huo X, Xu XJ, Zhang B, Du MG, Yang HW, Zheng LK, Li J and Shen ZY: Relationship between HPV16/18 E6 and 53, 21WAF1, MDM2, Ki67 and cyclin D1 expression in esophageal squamous cell carcinoma: comparative study by using tissue microarray technology. Exp Oncol 28: 235-240, 2006. 
23. Shen ZY, Hu SP, Lu LC, Tang CZ, Kuang ZS, Zhong SP and Zeng Y: Detection of human papillomavirus in esophageal carcinoma. J Med Virol 68: 412-416, 2002.

24. Shuyama K, Castillo A, Aguayo F, Sun Q, Khan N, Koriyama C and Akiba S: Human papillomavirus in high- and low-risk areas of oesophageal squamous cell carcinoma in China. Br J Cancer 96: 1554-1559, 2007.

25. Wang LS, Chow KC, Wu YC, Li WY and Huang MH: Detection of Epstein-Barr virus in esophageal squamous cell carcinoma in Taiwan. Am J Gastroenterol 94: 2834-2839, 1999.

26. Awerkiew S, Bollschweiler E, Metzger R, Schneider PM, Holscher AH and Pfister H: Esophageal cancer in Germany is associated with Epstein-Barr-virus but not with papillomaviruses. Med Microbiol Immunol 192: 137-140, 2003.

27. Chang F, Syrjanen S, Shen Q, Cintorino M, Santopietro R, Tosi P and Syrjanen K: Evaluation of HPV, CMV, HSV and EBV in esophageal squamous cell carcinomas from a high-incidence area of China. Anticancer Res 20: 3935-3940, 2000.

28. Anwar M, Koriyama C, Naveed IA, Hamid S, Ahmad M, Itoh T, Minakami Y, Eizuru Y and Akiba S: Epstein-barr virus detection in tumors of upper gastrointestinal tract. An in situ hybridization study in Pakistan. J Exp Clin Cancer Res 24: 379-385, 2005

29. Cho YJ, Chang MS, Park SH, Kim HS and Kim WH: In situ hybridization of Epstein-Barr virus in tumor cells and tumorinfiltrating lymphocytes of the gastrointestinal tract. Hum Pathol 32: 297-301, 2001.

30. Khurshid A, Kazuya N, Hanae I and Manabu I: Infection of human papillomavirus (HPV) and Epstein-Barr virus (EBV) and 553 expression in human esophageal carcinoma. J Pak Med Assoc 48: 138-142, 1998

31. Sunpaweravong S, Mitarnun W and Puttawibul P: Absence of Epstein-Barr virus in esophageal squamous cell carcinoma. Dis Esophagus 18: 398-399, 2005.

32. Yanai H, Hirano A, Matsusaki K, Kawano T, Miura O, Yoshida T, Okita K and Shimizu N: Epstein-Barr virus association is rare in esophageal squamous cell carcinoma. Int J Gastrointest Cancer 33: 165-170, 2003

33. Szostek S, Zawilinska B, Kopec J and Kosz-Vnenchak M: Herpesviruses as possible cofactors in HPV-16-related oncogenesis. Acta Biochim Pol 56: 337-342, 2009.

34. Sharma R, Palefsky JM: Addition of a single E2 binding site to the human papillomavirus (HPV) type 16 long control region enhances killing of HPV positive cells via HPV E2 proteinregulated herpes simplex virus type 1 thymidine kinase-mediated suicide gene therapy. Hum Gene Ther 21: 843-854, 2010.
35. Tsai JH, Hsu CS, Tsai CH, Su JM, Liu YT, Cheng MH, Wei JC, Chen FL and Yang CC: Relationship between viral factors, axillary lymph node status and survival in breast cancer. $\mathrm{J}$ Cancer Res Clin Oncol 133: 13-21, 2007.

36. Gazzaniga P, Vercillo R, Gradilone A, Silvestri I, Gandini O, Napolitano M, Giuliani L, Fioravanti A, Gallucci M and Agliano AM: Prevalence of papillomavirus, Epstein-Barr virus, cytomegalovirus, and herpes simplex virus type 2 in urinary bladder cancer. J Med Virol 55: 262-267, 1998.

37. Wang X, Tian X, Liu F, Zhao Y, Sun M, Chen D, Lu C, Wang Z Shi X and Zhang Q, Zhang D, Shen Z, Li F, Harris CC, Cai H and Ke Y: Detection of HPV DNA in esophageal cancer specimens from different regions and ethnic groups: a descriptive study. BMC Cancer 10: 19, 2010.

38. Shen ZY, Xu LY, Chen MH, Cai WJ, Shen J, Chen JY and Zeng Y: Cytogenetic and molecular genetic changes in malignant transformation of immortalized esophageal epithelial cells. Int J Mol Med 12: 219-224, 2003.

39. Kerroucha R, Hervieu V, Chambonniere ML, MegeLechevallier F, Poncet G, Boulez J, Taniere P and Scoazec JY: [Adenocarcinomas of the stomach and distal esophagus. Incidence and phenotypic characteristics of EBV-associated cases in the Lyons area, France]. Ann Pathol 24: 228-235, 2004.

40. Morewaya J, Koriyama C, Akiba S, Shan D, Itoh T and Eizuru Y: Epstein-Barr virus-associated gastric carcinoma in Papua New Guinea. Oncol Rep 12: 1093-1098, 2004.

41. Lanham S, Herbert A, Basarab A and Watt P: Detection of cervical infections in colposcopy clinic patients. J Clin Microbiol 39: 2946-2950, 2001.

42. Zur HH: Papillomaviruses causing cancer: evasion from host-cell control in early events in carcinogenesis. J Natl Cancer Inst 92: 690-698, 2000.

43. Zur HH: Papillomaviruses and cancer: from basic studies to clinical application. Nat Rev Cancer 2: 342-350, 2002.

44. Li TT, Zhao LN, Liu ZG, Han Y and Fan DM: Regulation of apoptosis by the papillomavirus E6 oncogene. World J Gastroenterol 11: 931-937, 2005.

45. Thompson MP and Kurzrock R: Epstein-Barr virus and cancer. Clin Cancer Res 10: 803-821, 2004.

46. Pagano JS, Blaser M, Buendia MA, Damania B, Khalili K, Raab-Traub $\mathrm{N}$ and Roizman B: Infectious agents and cancer: criteria for a causal relation. Semin Cancer Biol 14: 453-471, 2004.

47. Hanari N, Matsubara H, Hoshino I, Akutsu Y, Nishimori T, Murakami K, Sakata H, Miyazawa Y and Ochiai T: Combinatory gene therapy with electrotransfer of midkine promoter-HSV-TK and interleukin-21. Anticancer Res 27: 2305-2310, 2007. 